\title{
Does hazelnut husk compost (HHC) effect on soil water holding capacity (WHC)? An environmental approach
}

\author{
Tayfun Aşkın*, Selahattin Aygün
}

Ordu University Agricultural Faculty Department of Soil Science and Plant Nutrition, Ordu, Turkey

\begin{abstract}
In this study, we applied hazelnut husk waste that was composted by using microbial biotechnological techniques into soil in the field conditions. The hazelnut husk compost (HHC) was applied in two hazelnut orchards having different textures such as sandy loam (SL) and clay loam (CL) soils and used different application rates $(0,1.25,2.5,5.0$, 7.5 and $10 \mathrm{t} \mathrm{da}^{-1}$ ). Soil sampling was done four times in a year (spring, summer, fall and winter). We investigated the effects of HHC on soil water holding capacity related to available water content of soil at both field capacity (FC) and permanent wilting point (PWP) with weight basis. Soil moisture coefficients were determined by using pressure plate and indicated as percentage weights at FC $(-33 \mathrm{kPa})$ and PWP $(-1500 \mathrm{kPa})$. Our results showed that $\mathrm{HHC}$ doses, sampling periods and soil textures effected soil water holding capacity at both FC and PWP. In addition, FC and PWP were found the highest at $10 \mathrm{t} \mathrm{da}^{-1}$ application dose. Findings of this study, the huge importance of HHC that related to protect soil water without harmful to the environment emphasized.
\end{abstract}

Keywords: Field capacity, permanent wilting point, hazelnut husk, environment, soil. (C) 2018 Federation of Eurasian Soil Science Societies. All rights reserved

\section{Introduction}

During the recent, the general concern about the environment and its preservation is increasing. If valuable organic wastes are not well managed, they can create environmental problems. Hazelnut husk is consist of green piece of hazelnut. There are a lot of hazelnut husk in orchards as a waste. Composting is one of the environmental friendly options to reuse this product. Currently, composting is accepted as a sustainable strategy to maintain agricultural ecosystems in an environmentally safe manner (Jiang et al., 2015; Wang et al., 2015). This method is considered to reduce carbon emissions and improve land use. It is an effective process that converts different organic solid waste materials into stable organic products applied in agriculture under optimized control conditions, thereby recycling waste materials (Rynk, 1992; Gülser et al., 2015).

The compost of hazelnut husk waste should use as an organic material in soils after hazelnut harvesting. Applied hazelnut husk compost (HHC) into soils increases soil fertility. Because of hazelnut husk compost includes high in organic matter content, available plant nutrients improve soil physical, chemical and biological properties, and they may increase crop yield. Soil organic carbon can strongly influence aggregation processes, and in turn is influenced by the types of plant residues or organic amendments used and by their decomposition rate and products (Bronick and Lal, 2005; Hati et al., 2007). Hazelnut husk waste is picked up in the hazelnut orchards to prevent its harmful effect for environment and it is used in soils improving of soil quality parameters such as organic matter content, field capacity and permanent wilting point etc. Organic materials and wastes can used to as a compost

\footnotetext{
${ }^{*}$ Corresponding author.

Ordu University Agricultural Faculty Department of Soil Science and Plant Nutrition, Ordu, Turkey

Tel.: +90452 2265200

e-ISSN: 2147-4249
}

E-mail address: tayfuna@odu.edu.tr DOI: $10.18393 /$ ejss.337222 
material. Hazelnut husk which is organic waste is produced about 500000 tonnes per year in Turkey. The Black Sea Region is an important area for hazelnut production (Kizllkaya et al., 2015a,b).

Soil water holding capacity is an important soil physical property that is used to evaluate soil quality. Plant available water capacity is the difference in water content between field capacity (33kPa) and permanent wilting point $(-1500 \mathrm{kPa})$, it is important so much for crop production because of plant uptake this water in the soils via their roots. Crops use available water more effectively. Additionally hazelnut husk compost waste has high in water holding capacity (Gupta et al., 1977; Klute anf Jacop, 1950; Kızllkaya et al., 2015a,b).

Importance of water increases day after day in the world. Water is an important vital matter for all living, plants and people. All livings need to water to alive. To provide continuity of water in soils is possible by its preservation. In soils to conserve water soil physical, chemical and biological properties must be improved by organic materials, wastes and other soil regulator. Hazelnut husk compost effects on soil quality related to physical properties such as water holding capacity, hydraulic conductivity, field capacity and permanent wilting point. Plants use water effectively between water content at field capacity ( $-33 \mathrm{kPa})$ and permanent wilting point $(-1500 \mathrm{kPa})$ in soil (Klute anf Jacop, 1950; Gupta et al., 1977). Soil organic carbon content was positively correlated with available water content (Evrendilek at al., 2004; Kizllkaya et al., 2015a,b). Application of organic wastes to soil increase soil organic matter content, soil available macronutrients, water holding capacity, porosity, infiltration capacity, hydraulic conductivity, water stable aggregation, and decrease bulk density and surface crusting (Khaleel et al., 1981; Haynes and Naidu, 1998; Matsi et al., 2003; Gülser et al., 2015).

Our aim is to investigate the effect of hazelnut husk compost (HHC) on soil water holding capacity (WHC) at both field capacity (FC) and permanent wilting point (PWP) related to available soil water content for plant with an environmental approach.

\section{Material and Methods}

Hazelnut husk (C/N ratio 55.71; $\mathrm{pH} 5.81 ; \mathrm{EC}_{25^{\circ} \mathrm{C}} 1.93 \mathrm{dSm}^{-1} ; 0.97 \% \mathrm{~N}$ ) was collected from the hazelnut orchard, was inoculated with carbon and the microorganisms used as an energy source was composted by windrow method and was used as a material in experiments using a windrow machine in the Research Facility of Soil Science and Plant Nutrition Department in Ondokuz Mayis University, Samsun, Turkey. HHC properties are as follows: $\mathrm{pH}$ is $6.76, \mathrm{EC}_{25^{\circ} \mathrm{C}}$ is $3.56 \mathrm{dS} \mathrm{m}^{-1}$, organic matter (OM) content is $94.75 \%$, total $\mathrm{N}$ content is $2.48 \%$, and C/N ratio is 22.16 (Kizllkaya et al., 2015a,b).

Field experiments were based on with randomized complete block design were conducted in two different hazelnut orchard with different textures (sandy loam; sand $76.14 \%$, silt $9.62 \%$, clay $14.24 \%, \mathrm{pH} 6.23, \mathrm{EC}{ }_{25^{\circ} \mathrm{C}}$ $0.04 \mathrm{dSm}^{-1}$, Soil organic matter (SOM) 1.41\% and clay loam; sand\% 33.55, silt\% 27.86, clay\% 38.53, pH 6.69, $\mathrm{EC}_{25^{\circ} \mathrm{C}} 1.43 \mathrm{dS} \mathrm{m}^{-1}$, SOM 2.58\%) located in Ordu district at the Black Sea Region of Turkey in November 2012. HHC was incorporated into the top $20 \mathrm{~cm}$ of the soil around the plant canopy without mixing any other material using a hoe in six application doses with three replication. Total experiment consisted of 36 parcels in order to increase the content of soil organic matter by $0,0.5 \%$ (1.25 ton $\left.\mathrm{da}^{-1}\right), 1 \%$ (2.5 ton $\left.\mathrm{da}^{-1}\right), 2 \%$ ( 5 ton $\left.\mathrm{da}^{-1}\right), 3 \%\left(7.5\right.$ ton $\left.\mathrm{da}^{-1}\right)$ and 4\% (10 ton $\left.\mathrm{da}^{-1}\right)$. Soil samplings were done at the end of the March, June, September and December 2013) to determine water content with weight basis at soil field capacity and permanent wilting point. In statistical analysis, MINITAB Statistic 17.0 program was used (Kızılkaya et al., 2015a,b).

\section{Results and Discussion}

Applying of hazelnut husk compost (HHC) into soils increased soil moisture content (weight basis) at both field capacity (FC) and permanent wilting point (PWP). We found that applying of HHC with increasing doses increased water content at both FC and PWP in hazelnut orchards. The highest water content at field capacity obtained 10 ton $\mathrm{da}^{-1}$ application dose (\%44.05) and the lowest water content at field capacity obtained in control. Effect of HHC application on FC was found statistically very important $(\mathrm{p}<0.001)$ effect. Also soil moisture coefficient was affected by texture at FC (Table 1, Figure 1). Organic waste and manure application increased water content at field capacity (Angın and Yağanoğlu, 2009).

Our results showed that soils with clay loam in texture (\%44.9) have higher water content at FC than sandy loam soils (\%34.5). The highest water content at FC was found in winter condition and the lowest water content at FC was found in summer condition (Figure 1). Soil x HHC application x sampling time interaction is not statistically important at FC (Figure 2). Field capacity was influenced by the application of different organic materials and compost application (Sohail-Ur-Raza et al., 2015). 
Table 1. ANOVA for FC values $(n=144)$

\begin{tabular}{llllll}
\hline Source & DF & Seq SS & Adj SS & F value & P value \\
\hline Soils (a) & 1 & 3894,8 & 3894,8 & 323,20 & 0,000 \\
HHC Doses (b) & 5 & 1618,3 & 323,67 & 26,86 & 0,000 \\
Sampling Time (c) & 3 & 148,9 & 49,62 & 4,12 & 0,009 \\
(a) x (b) & 5 & 333,7 & 66,75 & 5,54 & 0,000 \\
(a) x (c) & 3 & 286,0 & 95,35 & 7,91 & 0,000 \\
(b) x (c) & 15 & 391,8 & 26,12 & 2,17 & 0,013 \\
(a) x (b) x (c) & 15 & 200,1 & 13,34 & 1,11 & 0,361 \\
Error & 96 & 1156,9 & 12,05 & & \\
Total & 143 & 8030,6 & & & \\
\hline
\end{tabular}

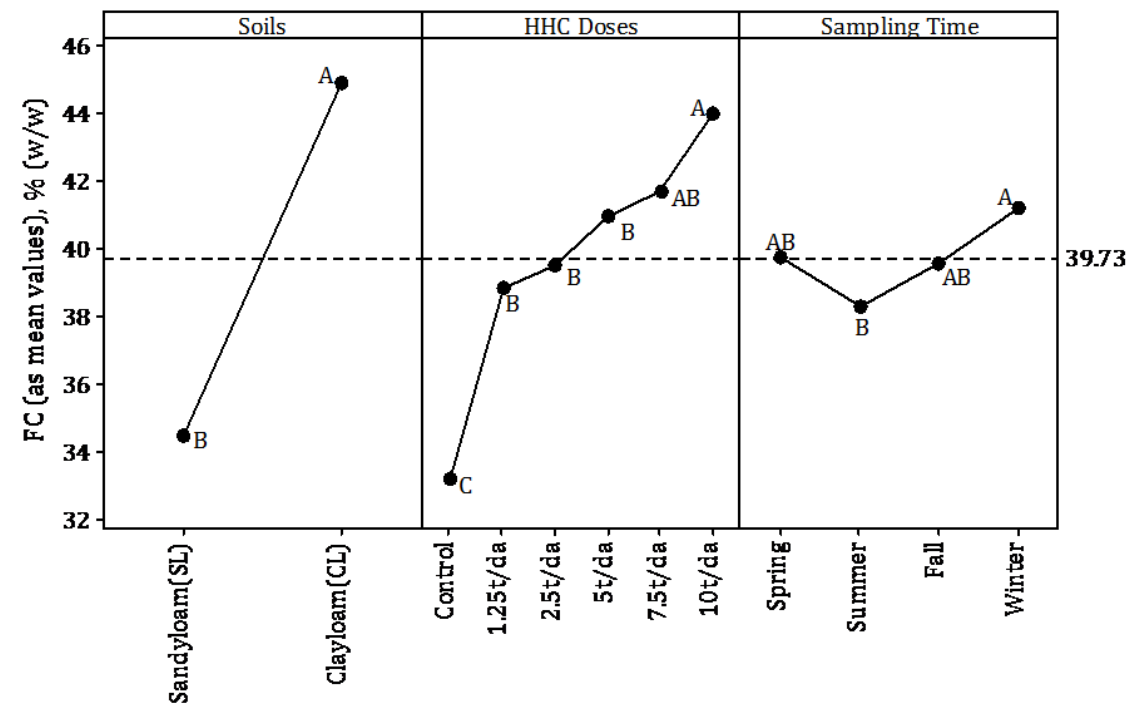

Figure 1. Main effects of soil texture, HHC doses and sampling time on the FC (means that do not share a letter are significantly different at $\mathrm{p}<0,01$ ).

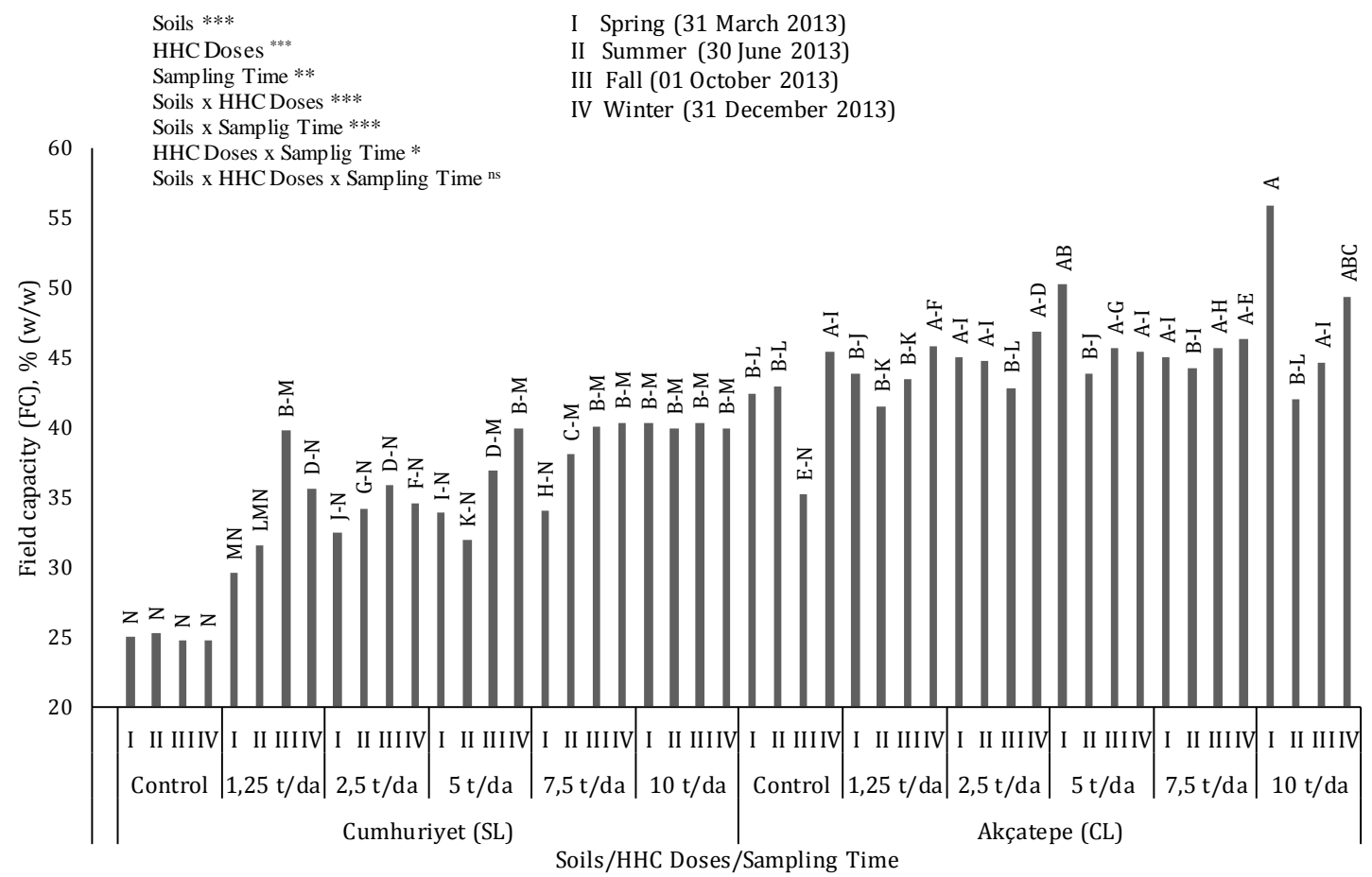

Figure 2. Effects of soil texture, HHC application and sampling time on FC (ns: non significant; *: p<0,05; **: p<0,01; ***: $\mathrm{p}<0,001 ;$ means that do not share a letter are significantly different at $\mathrm{p}<0,05$ ). 
Increases in the mean FC values according to soil textures and HHC doses were presented in Figure 3. Increasing of FC values (as mean value) depending of its texture were different. Increases of the FC were lower in clay loam (CL) soil than sandy loam soil (SL) in soil textures. Increases of FC for coarse-textured soils are larger than fine-textured soils (Gupta et al., 1977; Unger and Stewart, 1974). The results showed that effect of application dose of HHC, soil textures and sampling time on PWP were found statistically important $(\mathrm{p}<0,001)$ effect (Table 2, Figure 4).

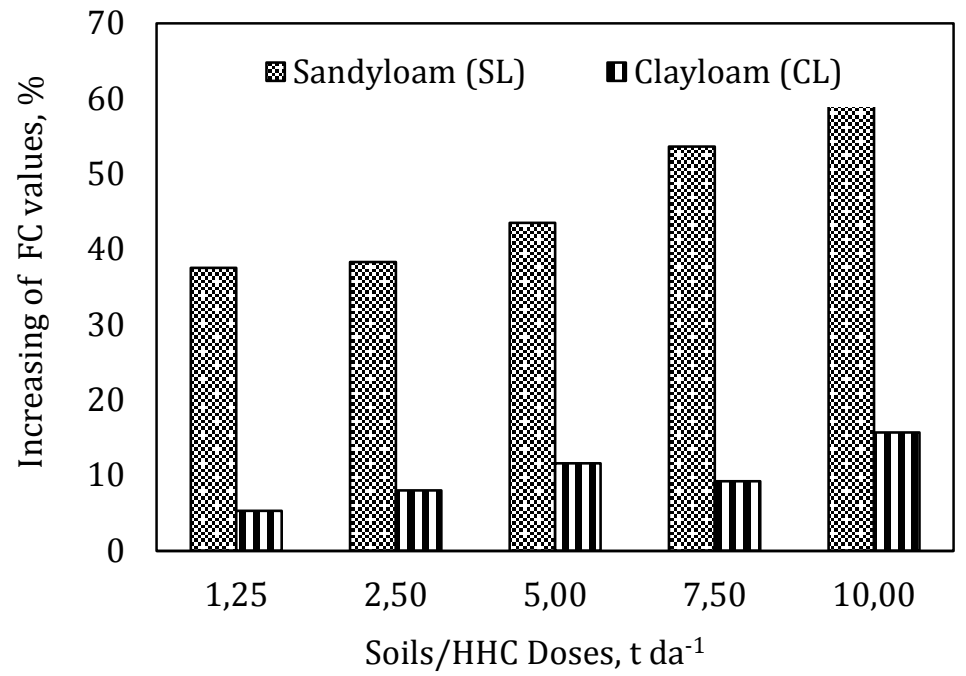

Figure 3. The comparison of FC values as a function of soils and HHC doses.

Table 2. ANOVA for PWP values ( $\mathrm{n}=144)$

\begin{tabular}{llllll}
\hline Source & DF & Seq SS & Adj MS & F value & P value \\
\hline Soils (a) & 1 & 7314,5 & 7314,53 & 2117,51 & 0,000 \\
HHC Doses (b) & 5 & 1448,3 & 289,65 & 83,85 & 0,000 \\
Sampling Time (c) & 3 & 566,3 & 188,78 & 54,65 & 0,000 \\
(a) x (b) & 5 & 417,6 & 83,51 & 24,18 & 0,000 \\
(a) x (c) & 3 & 118,4 & 39,46 & 11,42 & 0,000 \\
(b) x (c) & 15 & 224,5 & 14,97 & 4,33 & 0,000 \\
(a) x (b) x (c) & 15 & 333,7 & 22,24 & 6,44 & 0,000 \\
Error & 96 & 331,6 & 3,45 & & \\
Total & 143 & & & & \\
\hline
\end{tabular}

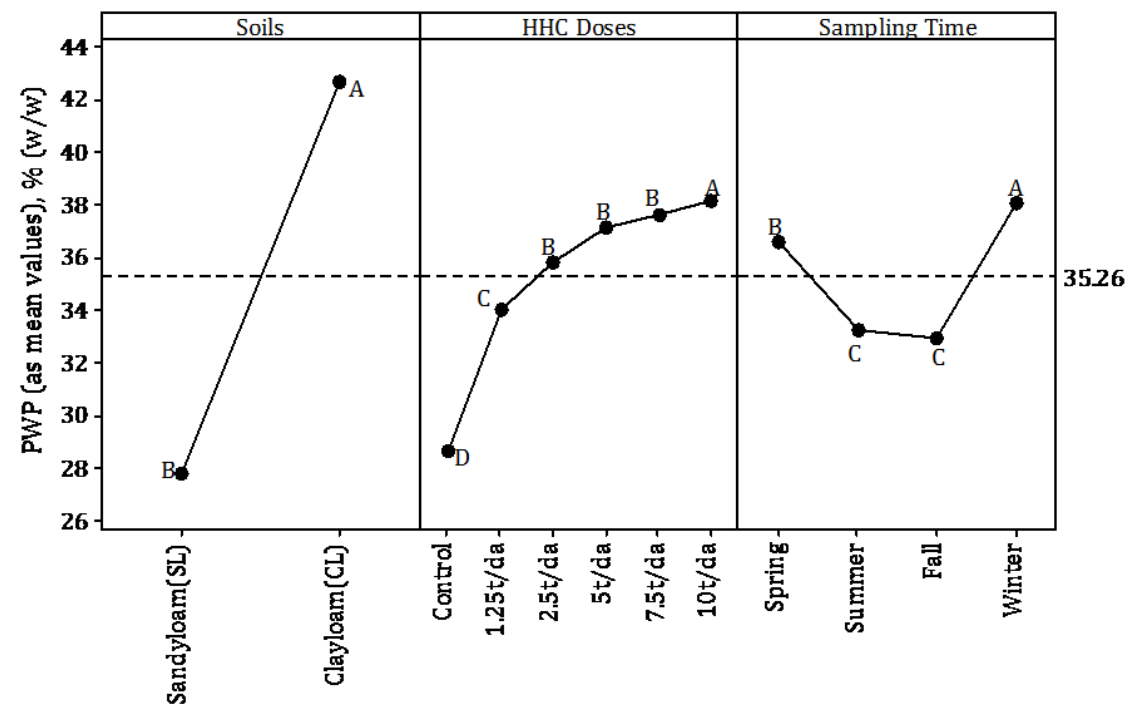

Figure 4. Main effects plot of soil texture, HHC doses and sampling time on the PWP (means that do not share a letter are significantly different at $\mathrm{p}<0,001$ ). 


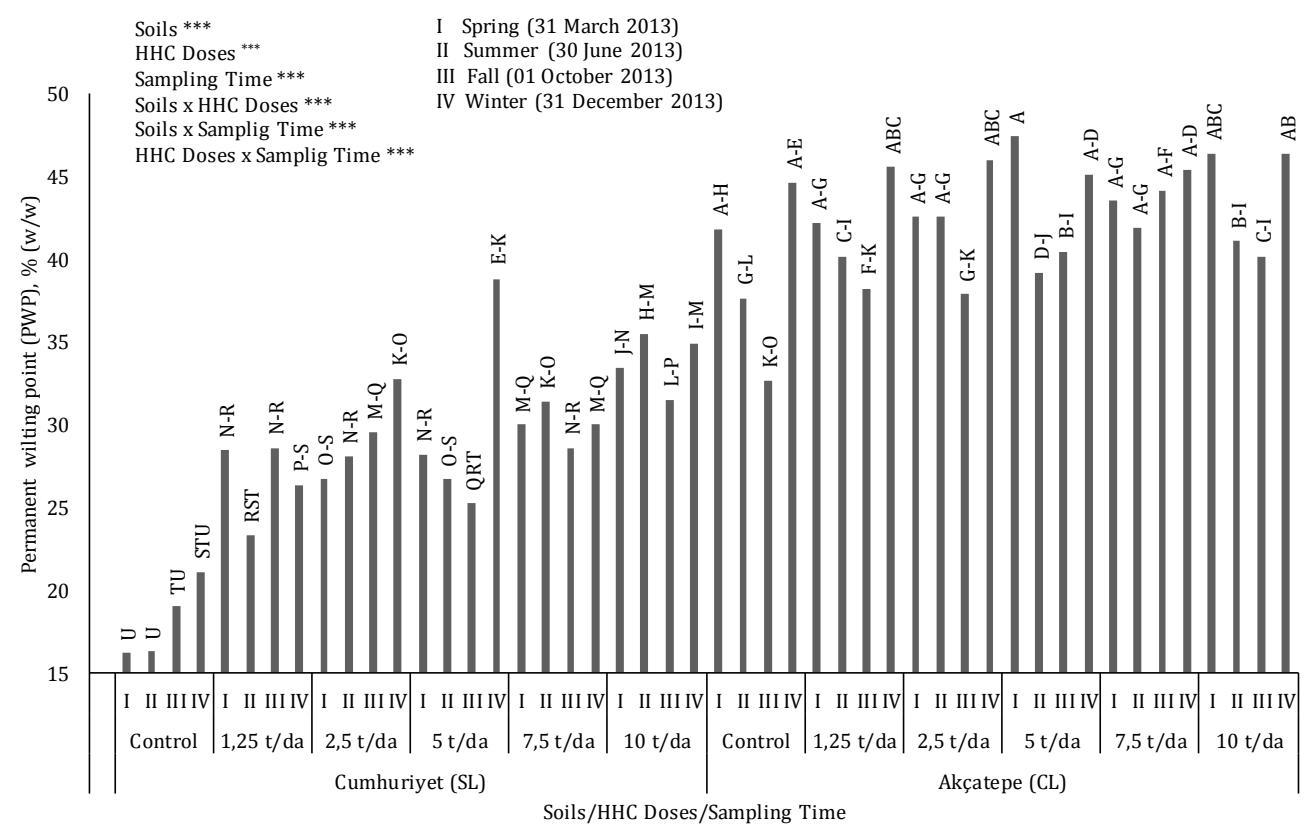

Figure 5: Effects of soil texture, HHC application and sampling time on PWP $\left(*\right.$ : $p<0,05 ;{ }^{* *}$ : $p<0,01 ;{ }^{* *}$ : $p<0,001$; means that do not share a letter are significantly different at $p<0,05$ ).

Increases in the mean PWP values according to soil textures and HHC doses were presented in Figure 6. Increasing of PWP values (as mean value) depending of its texture were different. Increases of the PWP were lower in clay loam (CL) soil than sandy loam soil (SL) in soil textures. The available data on changes in water holding capacity at both FC and PWP as a result of organic waste application were reported by numerous study. For example, increases of PWP for coarse-textured soils are larger than fine-textured soils (Gupta et al., 1977; Unger and Stewart, 1974).

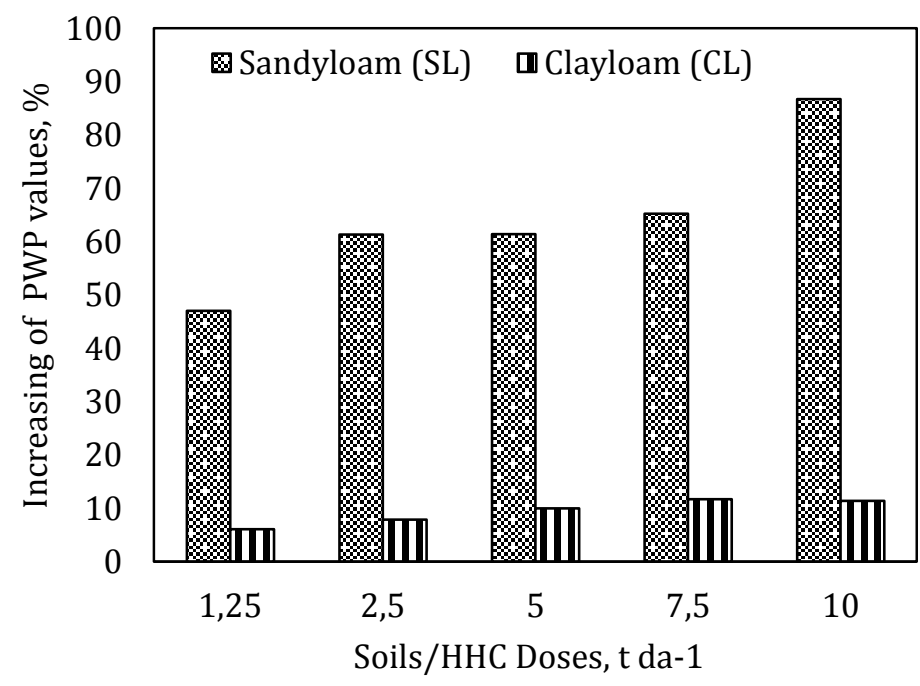

Figure 6. The comparison of PWP values as a function of soils and HHC doses.

\section{Conclusion}

Application of HHC in soil as an organic waste increased the soil organic matter content, water holding capacity (WHC) on a weight basis at both filed capacity (FC) and permanent wilting point (PWP), with an increase in HHC application doses during the studied incubation time. WHC (weight basis) at both FC and PWP increases with HHC addition rates varying of soil texture and soil sampling time. For coarse-textured soil, HHC application has greater effect than fine textured soil on FC and PWP. As a waste, hazelnut husk 
picked up hazelnut orchards. Hazelnut husk is a waste for environment and it has high in organic matter content so it should use as a carbon and nitrogen source for soil biota and crops. Hazelnut husk compost applied to soils both for a valuable nitrogen source for soils and plants and its harmful effect is obstructed on the environment. Additionally HHC increased soil moisture content due to higher infiltration and water holding capacity so runoff and soil erosion is decreased. Soil moisture content effects all microorganism and living in soils. If moisture content increase in the soils, all living organism must use it so it will be healthier for environment conditions. More clean environment more healthy life comes from soil.

These findings seem to confirm that the HHC applications are friendly for environment. This fact suggests that the use of HHC supports soil water retention relating of soil water save.

\section{Acknowledgement}

This study was financially supported by TUBITAK (The Scientific and Technical Research Council of Turkey) with Project no. 1190698. Authors thank to TUBITAK.

\section{References}

Angın İ., Yağanoğlu A. V., 2009. Arıtma çamurlarının fiziksel ve kimyasal toprak düzenleyicisi olarak kullanımı. Ekoloji 19 (73): 39-47. [in Turkish]

Bronick,, C.J., Lal, R., 2005. Soil structure and management: A review. Geoderma 124(1-2): 3-22.

Evrendilek, F., Celik, I., Kilic, S., 2004. Changes in soil organic carbon and other physical soil properties along adjacent Mediterranean forest, grassland, and cropland ecosystems in Turkey. Journal of Arid Environments 59(4): 743752.

Gupta, S.C., Dowdy, R.H., Larson, W.E., 1977. Hydraulic and thermal properties of a sandy soil as influenced by incorporation of sewage-sludge. Soil Science Society of America Journal 41(3): 601-605.

Gülser, C., Candemir, F., Kanel, Y., Demirkaya, S., 2015. Effect of manure on organic carbon content and fractal dimensions of aggregates. Eurasian Journal of Soil Science 4(1): 1-5.

Hati, M.K., Swarup, A., Dwivedi, A.K., Misra, A.K., Bandyopadhyay, K.K., 2007. Changes in soil physical properties and organic carbon status at the topsoil horizon of a vertisol of central India after 28 years of continuous cropping, fertilization and manuring. Agriculture, Ecosystems and Environment 119(1-2): 127-134.

Haynes, R.J., Naidu, R., 1998. Influence of lime, fertilizer and manure applications on soil organic matter content and soil physical conditions: a review. Nutrient Cycling in Agroecosystems 51(2): 123-137.

Jiang, J., Liu, X., Huang, Y., Huang, H., 2015. Inoculation with nitrogen turnover bacterial agent appropriately increasing nitrogen and promoting maturity in pig manure composting. Waste Management 39:78-85.

Khaleel, R., Reddy, K.R., Overcash, M.R., 1981. Changes in soil physical properties due to organic waste applications: a review. Journal of Environmental Quality 10(2): 133-141.

Kızılkaya, R., Sahin, N., Askin, T., Sushkova, S., 2015a. Isolation, characterization and genetic identification of natural fungal strains from decomposing hazelnut husk. $50^{\text {th }}$ Croatian $\& 10^{\text {th }}$ International Symposium on Agriculture. February 16-20, 2015. Opatija, Crotia.

Kızılkaya, R., Sahin, N., Tatar, D., Veyisoglu, A., Askin, T., Sushkova, S.N., Minkina, T., 2015b. Isolation and identification of bacterial strains from decomposing hazelnut husk. Compost Science \& Utilization 23(3): 173-184

Klute, A., Jacop, W.C., 1950. Physical properties of Sassafras silt loam as affected by long-time organic matter additions. Soil Science Society of America Journal 14:24-28.

Matsi, T., Lithourgidis, A.S., Gagianas, A.A., 2003. Effects of injected liquid cattle manure on growth and yield of winter wheat and soil characteristics. Agronomy Journal 95(3): 592-596.

Rynk, R., 1992. On-Farm Composting Handbook. Northeast Regional Agricultural Engineering Service, NRAES-54, Ithaca, New York, USA.

Sohail-Ur-Raza, M., Ahmed, Z.I., Malik, M.A., Ijaz, S.S., 2015. Effective soil additives for improved soil water retention. Pakistan Journal of Agricultural Sciences 52(1): 463-468.

Unger, P.W., Stewart, B.A., 1974. Feedlot waste effects on soil conditions and water evaporation. Soil Science Society of America Journal 38(6): 954-957.

Wang, X., Ciu, H., Shi, J., Zhao, Y., Wei, Z., 2015. Relationship between bacterial diversity and environmental parameters during composting of different raw materials. Bioresource Technology 198: 395-402. 